\title{
Interpretation of Shoreline-Position Data For Coastal Engineering Analysis
}

PURPOSE: To provide background information and guidance for interpreting shorelineposition data. Such data are analyzed for assessing historic and recent shoreline change, estimating impacts of jetties and navigation channels on adjacent shorelines, formulating sediment budgets, and calibrating and verifying numerical models of shoreline response. This Technical Note reviews definitions of the shoreline, their relation to the data sources, and characteristics of the observed shoreline shape or signal that reflects the acting processes and measurement procedure.

BACKGROUND: Shoreline position and its rate of change constitute basic information required for conducting many coastal engineering studies. Recently, Geographic Information Systems are being applied within the U.S. Army Corps of Engineers (USACE) and by its contractors to build comprehensive databases on shoreline change. In many projects, the first available data may have been collected in the mid to late 1800s, when the Survey of the Coast was begun by the U.S. Coast and Geodetic Survey, the predecessor organization of the present National Ocean Service (NOS) of the National Oceanic and Atmospheric Administration. Because inlet systems alter sediment-transport processes on a regional scale spanning decades and centuries, these older data will be analyzed together with contemporary data. As older shoreline-position data are accessed and combined with more modern data, awareness and understanding of the properties of databases that may span more than a century will improve consistency and accuracy, as well as reduce the potential for arriving at erroneous conclusions about shoreline change.

DEFINITIONS OF THE SHORELINE: The shoreline is the intersection of water, land, and air. The intersection can refer to a particular time or can be defined more abstractly, such as referenced to a mean intersection over a specified time interval. Because water level near the shore changes on many time scales, and the position of the shoreline is difficult to measure, definitions depend on the measurement method and the purpose of the measurement. In some publications, the same terminology has referred to different measurement procedures and, therefore, can be a source of confusion. This section discusses standard definitions, how they differ, and how shoreline-position measurements are made. Table 1 summarizes the discussion. Mean high water (MHW) is a tidal datum calculated as the average of all high-water elevations that occur in a standard 19-year period or tidal epoch called the National Tidal Datum Epoch (NTDE), presently 1960 to 1978 . The MHW datum is related to permanent local benchmarks and applies to a restricted coastal reach. The mean high-water shoreline (MHWL) is the intersection of the MHW at points alongshore. Acronyms associated with tidal datums and other terminology are summarized at the end of this Note. 


\begin{tabular}{|c|c|c|c|c|}
\hline No. & Definition & Measurement Procedure & $\begin{array}{l}\text { Related to } \\
\text { MHW? }\end{array}$ & Comments \\
\hline 1 & $\begin{array}{l}\text { Mapped } \\
\mathrm{MHWL}^{1}\end{array}$ & $\begin{array}{l}\text { Interpreted from aerial } \\
\text { photography combined with } \\
\text { water-level measurements }\end{array}$ & $\begin{array}{l}\text { Yes } \\
\text { Approx. }\end{array}$ & $\begin{array}{l}\text { Performed by NOS as part of its } \\
\text { mapping function. Approximately } \\
\text { related to the MHW tidal datum. }\end{array}$ \\
\hline 2 & $\begin{array}{l}\text { Surveyed } \\
\text { MHWL }\end{array}$ & $\begin{array}{l}\text { Beach profile survey tied to } \\
\text { MHW benchmarks at a tide } \\
\text { gauge }\end{array}$ & $\begin{array}{l}\text { Yes } \\
\text { Rigorous }\end{array}$ & $\begin{array}{l}\text { Typically performed for property } \\
\text { boundary delineation or as an } \\
\text { outcome of a beach profile surveying. } \\
\text { Accurately related to a tidal datum. }\end{array}$ \\
\hline 3 & HWL & $\begin{array}{l}\text { a. Interpreted from aerial } \\
\text { photographs } \\
\text { b. Located on the ground } \\
\text { by interpretation combined } \\
\text { with either land survey or } \\
\text { GPS }{ }^{2} \text { survey }\end{array}$ & No & $\begin{array}{l}\text { Definition and procedure employed by } \\
\text { early Federal topographers and in } \\
\text { modern topographic measurements. } \\
\text { Not related to a tidal datum or fixed } \\
\text { elevation, but, typically, the location of } \\
\text { the berm crest or foot of dune or cliff. }\end{array}$ \\
\hline 4 & Wetted bound & Aerial photography & No & $\begin{array}{l}\text { Highly dependent on beach, water } \\
\text { level, wave, and wind properties. Not } \\
\text { related to a vertical datum. }\end{array}$ \\
\hline 5 & Water line & Aerial photography & No & $\begin{array}{l}\text { Line of the instantaneous beach-water } \\
\text { intercept. Not related to a vertical } \\
\text { datum. }\end{array}$ \\
\hline 6 & $\begin{array}{l}\text { Dune line } \\
\text { Cliff line }\end{array}$ & $\begin{array}{l}\text { Aerial photography; } \\
\text { topographic survey }\end{array}$ & No & $\begin{array}{l}\text { The dune line may not represent a } \\
\text { shoreline unless interpreted as a HWL } \\
\text { on a narrow beach without a berm. } \\
\text { Not related to a tidal datum. }\end{array}$ \\
\hline
\end{tabular}

1. Mapped MHWL. There is some confusion in the literature between a MHWL determined from aerial photography (the mapped MHWL) and a MHWL determined by beach-profile survey (the surveyed MHWL). A true mapped MHWL is determined from controlled and rectified aerial photographs. However, this line is not the MHWL as would appear on a beach-profile survey, because the position to which water rises on the beach contains a contribution from runup and other possible sources of water-level change near to shore. Typically, the position of the mapped MHWLis expected to lie above the position of the surveyed MHWL. Water level on the coast exhibits a seasonal dependence (e.g., Lyles et al. 1988). On the Atlantic coast of the United States, monthly means in water level show a characteristic rise in summer and a drop in winter. On the Pacific coast this trend is opposite, showing a drop anywhere from spring through fall, and a rise in fall through winter. The seasonal pattern is more complex in the Gulf of Mexico and may show two distinct rises and falls in the year. These seasonal changes in water level, which are typically in the range of about 0.12 to $0.24 \mathrm{~m}(0.4$ to $0.8 \mathrm{ft})$, are attributed to changes in temperature of the oceans, El Niño, and other global phenomena. Intra-annual changes can deviate substantially from the long-term mean monthly change. Therefore, estimation of a MHWL by from aerial photographs without adjustment by ground truthing has the potential of introducing substantial error, depending on time of year and beach slope.

Similarly, there is confusion in the literature in identifying the mapped MHWL as the High Water Line, as described below. These two shorelines are not same, as discussed in Item 3.

2. Surveyed MHWL. The surveyed MHW line is determined through a beach-profile survey that is tied to benchmarks at a water-level gauge for which tidal datums are defined. The elevation of MHW (or any other datum) can be located on the profile, giving an accurate 
measurement of the position of the MHWL at that location and time. The collection of all points on the beach at the elevations of the MHW datum defines the MHWL.

3. HWL. The high- water line (HWL) is a shoreline position interpreted by visually locating and mapping some morphologic or other feature. The HWL is typically chosen as the seawardmost berm crest, if a berm exists (Figure 1). The HWL is not referenced to an elevation or a tidal datum, but to a notable feature that represents the upward limit reached by the water, whether or not it is tidal. Shalowitz $(1962,1964)$, an NOS authority on marine boundaries, wrote a twovolume definitive work on the subject. Shalowitz documented procedures followed by the early Federal surveyors (op cit. pp. 171-172): The most important feature on a topographic survey is the high-water line. It is the line that is used on the nautical charts of the Coast Survey as the dividing line between the land and water; the line that indicates whether the coast is building out or receding... From the standpoint of the surveyor, the high-water line is the only line of contact between land and water that is identifiable on the ground at all times and does not require the topographer being there at a specified time during the tidal cycle, or the running of levels. The high-water line can generally be closely approximated by noting the vegetation, driftwood, discoloration of rocks, or other visible signs of high tides.

Some authors have misinterpreted related material in Shalowitz (1964) as indicating that the topographically mapped MHWL is equivalent to the HWL. Careful reading proves this not true and that, indeed, Shalowitz intended to emphasize this was not the case. On many maps the shoreline is labeled as the "MHWL," but this is not true unless a tide-controlled survey was conducted. The original Description Report associated with the NOS map under study, if available, should be consulted for confirmation.

The HWL is, therefore, not the shoreline defined by MHW as sometimes marked on charts and maps published by the NOS and the U.S. Geological Survey (USGS). Early topographers and topographers today doing wide-area shoreline-position surveys could not and do not measure or refer to the MHW elevation in the field. Similarly, modern HWL surveys employ differential Global Positioning System (GPS) techniques (Morton et al. 1993; Byrnes and Hiland 1995) and trace the berm crest if one exists or the foot of the dune if the beach narrows such that water obviously reaches the dune (See Figure 1).

Some authors have assumed the HWL to be the wetted bound or the instantaneous shoreline, both described below. These assumptions are not correct because, at any given time, even at high tide, these shorelines may not correspond to the location of the berm crest on the beach.

4. Wetted bound. The wetted bound, or wet-beach/dry-beach intersection, is a line interpreted from a difference in color tone. It denotes the boundary between sand saturated at any time of tide, which appears darker (in field surveys or in aerial photographs), and drier sand landward of that limit, which appears lighter. The wetted bound has sometimes been interpreted or erroneously identified as the mapped MHWL or as the HWL. The previous paragraph and modern understanding of coastal processes indicate this is not the case, except by coincidence.

5. Water line. The water line is the interface between the instantaneous edge of the water and the beach. The water line may sometimes be distinguished as the edge of white water of the 
swash zone, wet or dry, on the beach face or berm. The water line is related to the stage of tide, and the elevation of runup and other nearshore water motions. The position of this line cannot be readily incorporated in quantitative analysis of shoreline-position change, because it represents a continuously.

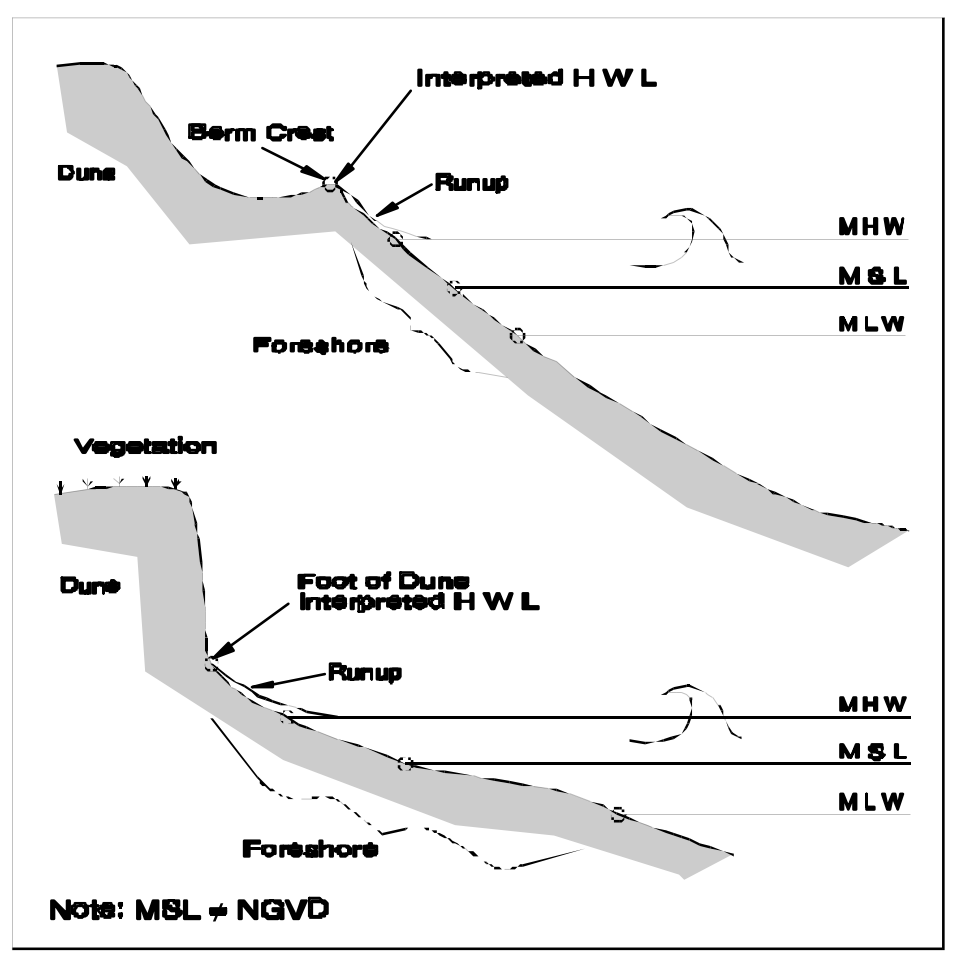

Figure 1. Schematic for identification of high-water shoreline.

6. Dune or cliff line. Typically, the dune line is interpreted as the location of the foot of the dune or cliff. Both the top and foot normally characterize cliffs and bluffs, if this information can be read from photographs. On an eroding coast, dunes, cliffs, and bluffs are expected to recede at different rates than the shoreline, because they are typically impacted only during times of extreme water levels. If no berm exists, and the water strikes the dune under normal water level and waves, then the foot of dune is identified as the HWL (see Item 3 and Figure 1).

CONTRIBUTIONS TO SHORELINE-POSITION SIGNAL: Values of shoreline position measured at a certain location alongshore and at a certain time reflect contributions from several natural processes. The recorded position of the shoreline is also influenced by the measurement and data-reduction procedure. Relative strengths of these signals will vary according to the coastal morphology, acting coastal processes, season, and the type and time of measurement.

The shoreline-position signal contains contributions from (1) the long-term trend, (2) cyclical variations, (3) random variations, (4) extreme events, (5) measurement procedure and accuracy, and (6) interpretation. The first four contributions are related to physical processes and site characteristics (including initial beach state and boundary conditions). The latter two contributions concern measurement procedure and data reduction. The six contributions are 
discussed individually below and summarized in Table 2. Figure 2 is a schematic illustrating typical characteristic features of each contribution.

1. Long-term trend. The long-term trend may contain independent contributions from longshore sand transport processes, cross-shore sand transport processes, relative sea-level rise, and underlying sedimentary structure. Erosion of the coast by storms can create an overall trend of shoreline recession. This trend might be erroneously attributed to longshore sand-transport processes, if care is not taken (Kraus 1997). The underlying or adjacent sedimentary structure, such as a clay base or rocky headland, can modify or constrain a long-term trend. At inlet jetties, longshore processes typically create an anti-symmetric shoreline shape (updrift advance and downdrift recession), whereas storm-induced erosion typically creates symmetric change, discussed in CETN IV-10 (Rosati and Kraus 1997). Often, the long-term trend is dominated by lateral boundary conditions imposed by jetties, inlets, headlands, and nodal points in transport (Rosati and Ebersole 1997). In shoreline analysis and numerical modeling, the typical goal is to quantify the long-term trend as a response to structures, boundary conditions, waves, relative sea-level change, and other factors acting at the study site. Quantification covers temporal scales from days for storms, to years for local impacts, to decades and beyond for regional changes. If adequate shoreline survey data over time are available, the standard deviation and other statistical quantities can quantify departures in shoreline position from the trend.

2. Cyclical variations. Seasonal change in beach width and shape is a cyclical component expected to be present in all shoreline-data compilations. Seasonal change involves a trend of shoreline advance in the summer and recession in the winter (Northern Hemisphere). In determining shoreline change, the comparison is most consistent if made for data sets corresponding to the same season to reduce contamination by summer-winter cyclical crossshore contributions.

Longshore sand waves (LSWs) and shoreline undulations, if present on a coast, are other prominent cyclical contributions that produce a rhythmic shoreline. LSWs are wave-like features that translate alongshore while maintaining form with lengths on the order of $1 \mathrm{~km}$ and amplitudes on the order of 10 to $100 \mathrm{~m}$ (Thevenot and Kraus 1995). Their speed has seasonal dependence and is on the order of $1 \mathrm{~km} /$ year. Sometimes called erosion waves and accretion waves, LSWs can confound shoreline-change interpretation. If advance and recession of the shoreline associated with the gradual translation of LSWs is not recognized, erroneous trends may be inferred. Undulations have not yet been well documented. Fixed wave-like undulatory features have been identified at some sites that appear to undergo cycles of shoreline advance and recession on the order of several years (similar to a standing wave). These cyclical features are distinct from the smaller-scale cusps and mega-cusps, discussed next. 


\begin{tabular}{|c|c|c|c|c|}
\hline \multicolumn{5}{|c|}{$\begin{array}{l}\text { Table } 2 \\
\text { Contributions to value of shoreline position (see Figure 2) }\end{array}$} \\
\hline No. & $\begin{array}{c}\text { Type of } \\
\text { Contribution }\end{array}$ & $\begin{array}{c}\text { Typical or } \\
\text { Example Processes } \\
\end{array}$ & $\begin{array}{c}\text { Typical } \\
\text { Spatial Scale } \\
\end{array}$ & $\begin{array}{c}\text { Typical Temporal } \\
\text { Scale }\end{array}$ \\
\hline 1 & Long-term trend & $\begin{array}{ll}\text { a. } & \text { Interception of littoral drift by } \\
& \text { structures } \\
\text { b. } & \text { Relative sea-level rise } \\
\end{array}$ & $\begin{array}{l}\text { Project scale to littoral } \\
\text { cell scale }\end{array}$ & Years to centuries \\
\hline 2 & Cyclical & $\begin{array}{l}\text { a. Seasonal change in beach } \\
\text { width; } \\
\text { b. Longshore sand waves }\end{array}$ & $\begin{array}{ll}\text { a. } & 30-100 \mathrm{~m} . \\
& \text { (across shore) } \\
\text { b. } & 0.5-1 \mathrm{~km} \\
& \text { (alongshore) } \\
\end{array}$ & Months \\
\hline 3 & Random & Cusps and mega-cusps & $1-100 m$ & Hours to days \\
\hline 4 & Extreme events & Large storms; beach fill & $\begin{array}{l}\text { Project scale to } \\
\text { regional scale }\end{array}$ & Hours to days \\
\hline 5 & $\begin{array}{l}\text { Measurement } \\
\text { procedure and } \\
\text { accuracy }\end{array}$ & $\begin{array}{ll}\text { a. } & \text { GPS survey } \\
\text { b. } & \text { Land survey } \\
\text { c. } & \text { Interpretation on ground } \\
\text { d. } & \text { Interpretation from } \\
& \text { photographs }\end{array}$ & Study site & -- \\
\hline 6 & $\begin{array}{l}\text { Identification and } \\
\text { assumption }\end{array}$ & $\begin{array}{l}\text { Identification of berm crest, foot of } \\
\text { dune, and wetted bound }\end{array}$ & Project scale & -- \\
\hline
\end{tabular}

3. Random variations. Randomness in shoreline change typically enters as local fluctuations alongshore that change with the wave conditions, on the order of hours to days. Randomness is associated with beach cusps and mega-cusps, changing mean and variance in the incident waves, and changing and irregular nearshore topography. Cusps appear and disappear according to the wave conditions and are not of near-permanent form (lasting over months) as are LSWs and undulations described in the preceding paragraphs. Rip-current embayments may appear at either regular or irregular intervals alongshore, as well as grow, diminish, or migrate according to the wave conditions. Because of short-term randomness, shoreline position can vary locally (order of $1-100 \mathrm{~m}$ ) from day to day.

4. Extreme events. In shoreline analysis, an inventory is done to identify extreme events (hurricanes or storms) that have occurred in the time interval being analyzed. The change produced by extreme events might mask or reverse trends associated with longshore transport. Similarly, beach fills and other engineering manipulations of the shoreline are inventoried and accounted for in the analysis of "extreme events." The process of tidal shoal breakup, reformation, and welding of shoals onto the adjacent shore can be viewed as quasi-cyclical or quasi-random. At the present time, shoal welding is not predictable and best viewed as a quasirandom extreme event.

5. Measurement procedure and accuracy. Measurement uncertainty and error have been treated extensively in the literature. Uncertainty and error are specific to the site, equipment, season, operator, and to the types of data being analyzed. Guidelines and standard-operating procedures are available for determining errors in shoreline position determined from aerial photographs (Anders and Byrnes 1991, Byrnes et al. 1991), from beach-profile surveys (Grosskopf and Kraus 1994), and from HWL surveys (Shalowitz 1964, Byrnes and Hiland 1995). 
Accuracy refers to the closeness a measurement is to the true value, whereas precision refers to how reproducible the measurement is, irrespective of the true value. For example, the precision of a land survey measurement of horizontal position and elevation on a sand beach might be less than $0.01 \mathrm{~m}$ for any coordinate, depending on the class of survey followed. For a differential GPS survey, the precision of measurement of horizontal position may be within, for example, ? $1 \mathrm{~m}$ and elevation to within half that amount. In analysis of aerial photographs, precision in determination of shoreline position depends on the scale of the pictures. Accuracy is discussed next, in Item 6.

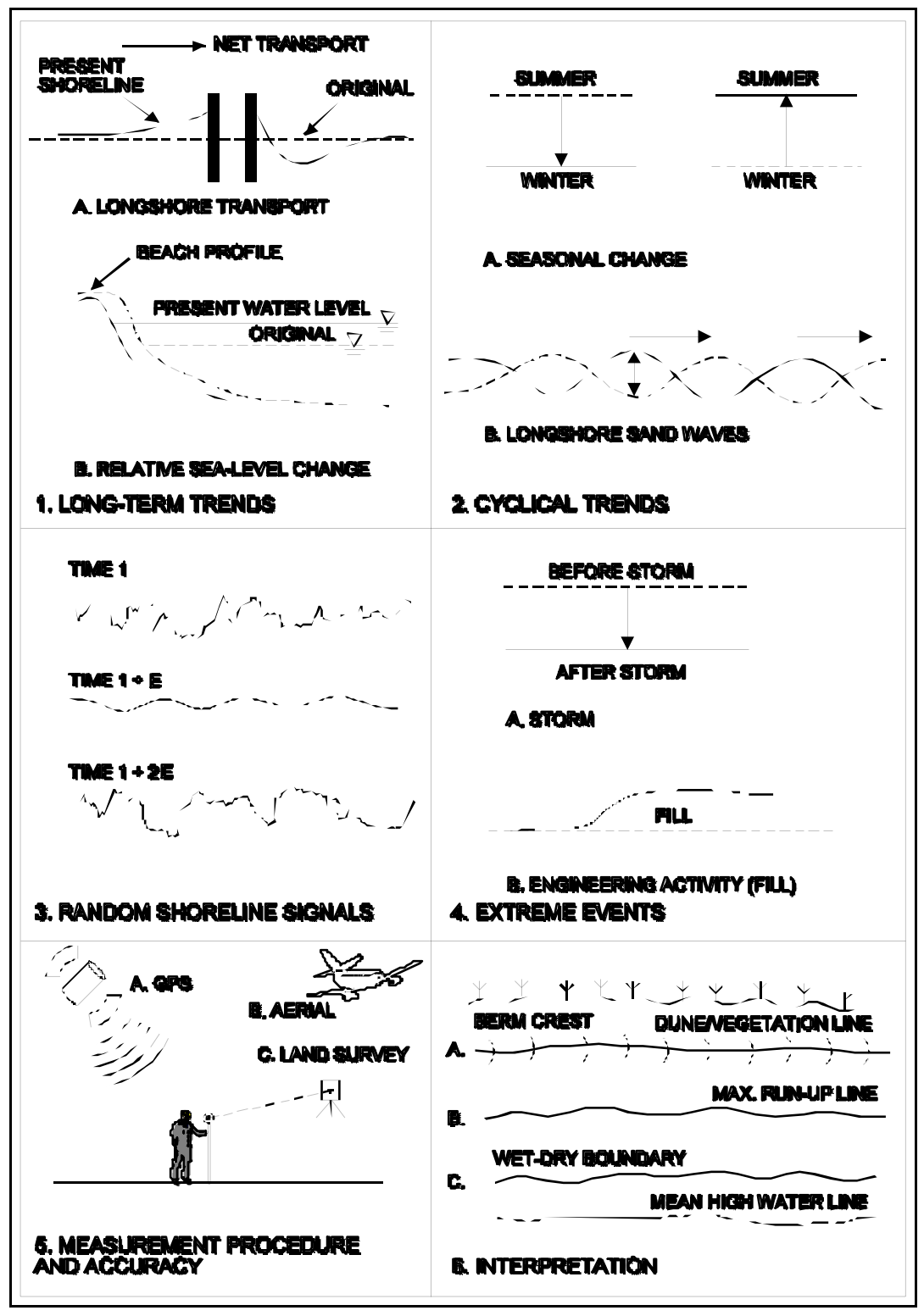

Figure 2. Schematic illustrating typical contributions to a shoreline position data set. 
6. Interpretation. Identification of and assumptions about the data enter both the dataacquisition and the data-output tasks of the analysis. Interpretation defines, to great extent, accuracy and not precision. For example, in interpreting shoreline position from aerial photographs (discussed in the next section), a HWL may be identified and digitized by one analyst (the recommended procedure), whereas another analyst might digitize the wetted bound (a procedure not recommended). The precision of either measurement might be quantifiable and small, but if the wrong line is identified, the result is a precise answer to the wrong question.

In compiling shoreline-position data that originate from different measurement procedures and, possibly, sources, care must be exercised in assuring consistency in definition of the shoreline and in comparing and analyzing logically consistent data. In the following, sources of shoreline position data are discussed together with aspects of their relation to the six types of contributions to the shoreline signal.

SOURCES OF SHORELINE-POSITION DATA: Data potentially suitable for shorelineposition analysis can be obtained from three sources, (1) topographic or HWL surveys, (2) aerial photography, and (3) beach-profile surveys. The purpose of this section is to clarify main properties of the data sets and discuss the potential for misinterpretation of the data in projects that involve different data sources. Further information can be found in Anders and Byrnes (1991) and Byrnes and Hiland (1995).

1. Topographic and HWL Surveys. This data source includes the earliest shoreline information. Topographic and HWL surveys are still performed, and they are expected to increase with in number with availability of GPS equipment.

2. Aerial Photography. A shoreline inferred from aerial photographs might be associated with the berm crest, the wetted bound, or the water line, as determined by visual interpretation of a discontinuity in color. The wetted bound, water line, and similarly inferred shoreline positions are instantaneous or near-instantaneous positions related to the water level, beach slope, beach sediments, wave and wind conditions, and water table at the time the photography was flown. Such a shoreline, without applying assumptions and corrections, may not represent the HWL (berm crest or foot of dune) or the MHWL.

As part of its Federal mapping responsibility, the NOS performs aerial photographic identification of the (approximate) position of the MHWL. If a rigorous aerial MHWL survey is conducted, temporary tide staffs are ins talled along the coast to observe water level. The staffs are connected to benchmarks and a long-term tide record so that the elevation of MHW along the beach is known. The photography is flown on a rising tide so that the greatest color distinction can be made between the wetted beach and the dry beach above it. When MHW is reached, the plane arrives on site and flies the coast. The result is a tide-controlled mapped MHWL. It is not the location of the true or surveyed MHWL along the coast because of the presence of runup and other short-period water motions, which raise the water-land intersection above the elevation of the still-water level (SWL). The analyst should be concerned as to whether a rigorous aerial survey was made or if surrogates, such as the wetted bound or HWL berm crest, were mapped to approximate the MHWL. 
The SWL is the elevation of the water with respect to some datum at a particular time as given by a water-level gauge located seaward of the surf zone. A water-level gauge removes shortperiod motions as associated with surface waves. Runup (and other motions such as infragravity waves) will place the elevation of the wetted bound and instantaneous shorelines far higher on the beach than the SWL.

The literature contains considerable misinformation and misinterpretation of the shoreline position that can be determined in aerial photography. Shorelines must be defined both accurately and consistently. Stafford (1971), a standard reference for analysis of coastal aerial photographs, equates the HWL with the boundary between wetted and dry beach (Stafford 1971, pg. 38). Further, Stafford quotes an earlier publication as ...maintaining that the difference between the high waterline represented by the last high tide and the mean high water line was insignificant for mapping purposes. The key operative phrase in the quotation is "for mapping purposes." These mapped shorelines are only rough approximations to, for example, the surveyed MHWL or to the HWL as discussed by Shalowitz (1964). For quantitative analysis of shoreline position and its change, mapping approximations may be unacceptable.

3. Beach-Profile Surveys. A MHWL can be determined from a carefully performed beachprofile survey tied to a benchmark. Vertical datum adjus tments relative to a reference datum (usually the National Geodetic Vertical Datum of 1929 or NGVD 29) are available from NOS, the USGS, the USACE and, in some states, from the state agency responsible for surveying and mapping. The surveyed MHWL is highly accurate, but limited to that point. The analyst must interpolate between lines spaced, typically, 300-500 m apart.

Note: NGVD 29, a standard geodetic reference for heights, is sometimes confused with or referred to synonymously as mean sea level (MSL). The datum MSL is defined by NOS as the average of the hourly values of water-level readings of a specific 19-year NTDE. However, because there are many variables controlling water level, and because a geodetic datum represents a best-fit surface over a broad area and not to a specific area, NGVD 29 is not, in general, equal to MSL. The geodetic datum can deviate from MSL by $0.3 \mathrm{~m}(1 \mathrm{ft})$ or more, depending on location. Thus, NGVD 29 and its replacement, the North American Vertical Datum of 1988 (NAVD 88), are not equal to MSL, do not bear a consistent relation to MSL along a coast, and are fixed, whereas the elevation of MSL typically changes slowly with time.

In the example which follows, the datums of mean higher high water (MHHW), mean low water (MLW), mean lower low water (MLLW), and mean tide level (MTL) are included for completeness. MLW is the average of all daily low waters. MHHW and MLLW are, respectively, the averages of the higher and lower waters in a tidal day. For example, if the tide has two highs in a day, only the higher water level of the two enters in computing MHHW. The tidal datum MTL is the average of MHW and MLW and is approximately equal to MSL. All datums are calculated over the NTDE.

\section{Example}

FIND: The differences in horizontal locations resulting from shoreline positions determined by aerial photography and by profile survey at the same general location on a beach. 
GIVEN: Aerial photography and profile-survey data available for the beach along Fire Island, located along the Atlantic south shore of Long Island, New York, for the latter part of March, 1995. Fire Island Beach Profile Lines F7 and F9 (see plan view on Fig. 3) were surveyed with an accurate sea-sled system (Grosskopf and Kraus 1994) and are shown in Figures 4a and 4b.

A visit to http://co-ops.nos.noaa.gov/ (NOS Center for Operational Oceanographic Products and Services web page) indicates the following tidal datums, referenced to MLLW, for Shinnecock Inlet (Atlantic Ocean gage), the closest ocean gage to the site: $\mathrm{MHHW}=1.15 \mathrm{~m} ; \mathrm{MHW}=1.06$ $\mathrm{m} ; \mathrm{MTL}=0.56 \mathrm{~m}$; and MLW $=0.05 \mathrm{~m}$. These datums were converted to elevations relative to NGVD as: $\mathrm{MHHW}=1.03 \mathrm{~m} ; \mathrm{MHW}=0.94 \mathrm{~m} ; \mathrm{MTL}=0.44 \mathrm{~m} ; \mathrm{MLW}=-0.07 \mathrm{~m}$; and $\mathrm{MLLW}=$ $-0.12 \mathrm{~m}$. Datums relative to NGVD are shown on Figures $4 \mathrm{a}$ and $4 \mathrm{~b}$.

Annotated on Figures 3 are geomorphic interpretations as lines indicating the locations of the foot of dune, wetted bound, and water line. As summarized in Table 1, these three demarcations are not defined through a vertical datum.

Inspection of Profiles F7 and F9 (Figures 4a and 4b) indicates berm-crest elevations of approximately 2.5 and $3.2 \mathrm{~m}$ NGVD. These elevations correspond to the berm crest line observed at the locations of Profiles F7 and F9 shown on the aerial photograph. Figures 4a and $4 \mathrm{~b}$ illustrate the different horizontal positions that will result in defining a shoreline as a mapped MHWL or as a HWL (berm crest), which can be interpreted from aerial photography. The intersection of MHW and the beach lies lower than the berm crest or interpreted HWL, and it is located from approximately 8 to $36 \mathrm{~m}$ seaward of the berm crest.

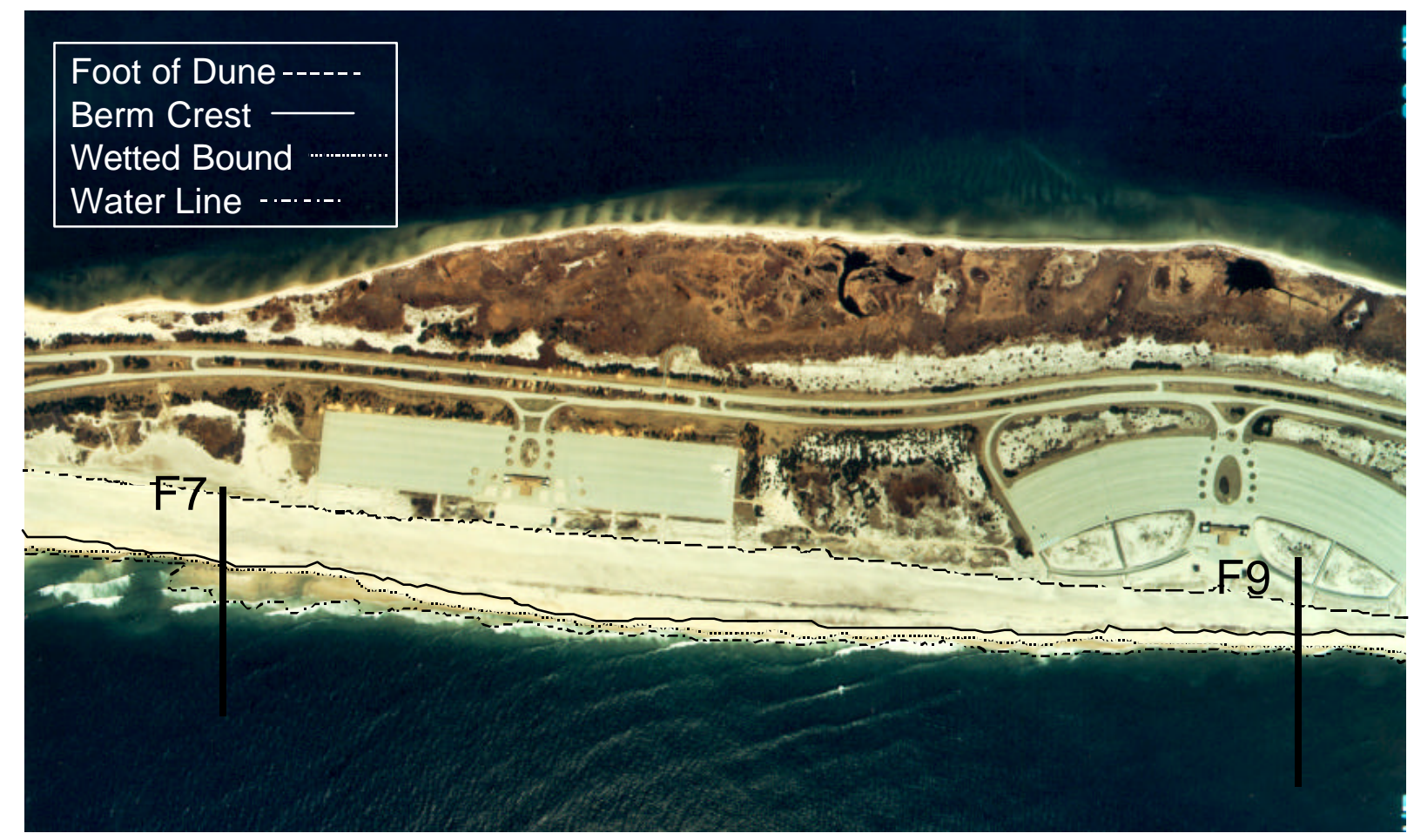

Figure 3. Aerial photograph, Fire Island, New York, March 29, 1995, with locations of Profiles F7 and F9 superimposed. 


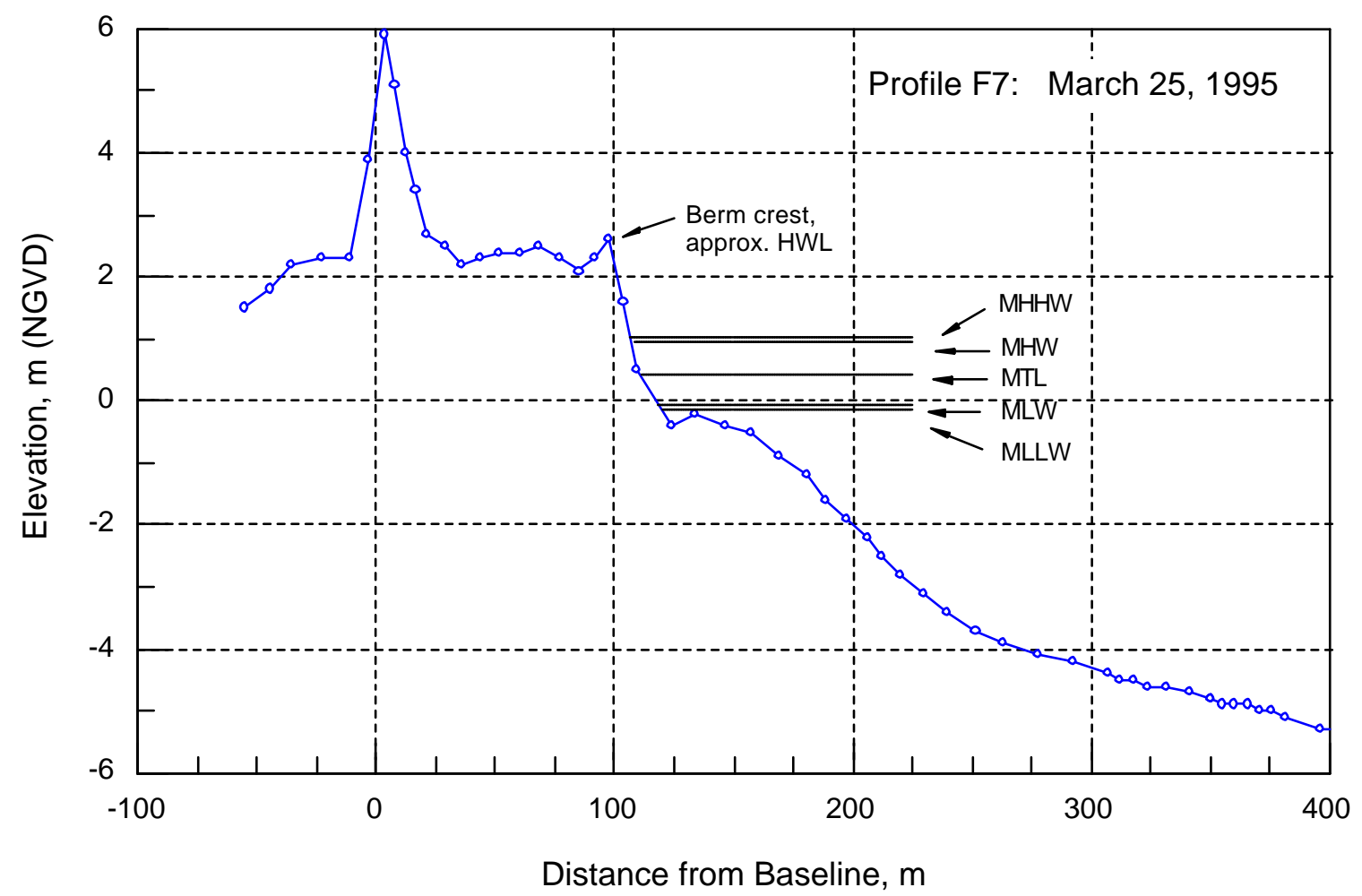

Figure 4a. Fire Island, New York profile survey data, Profile F7, March 25, 1995.

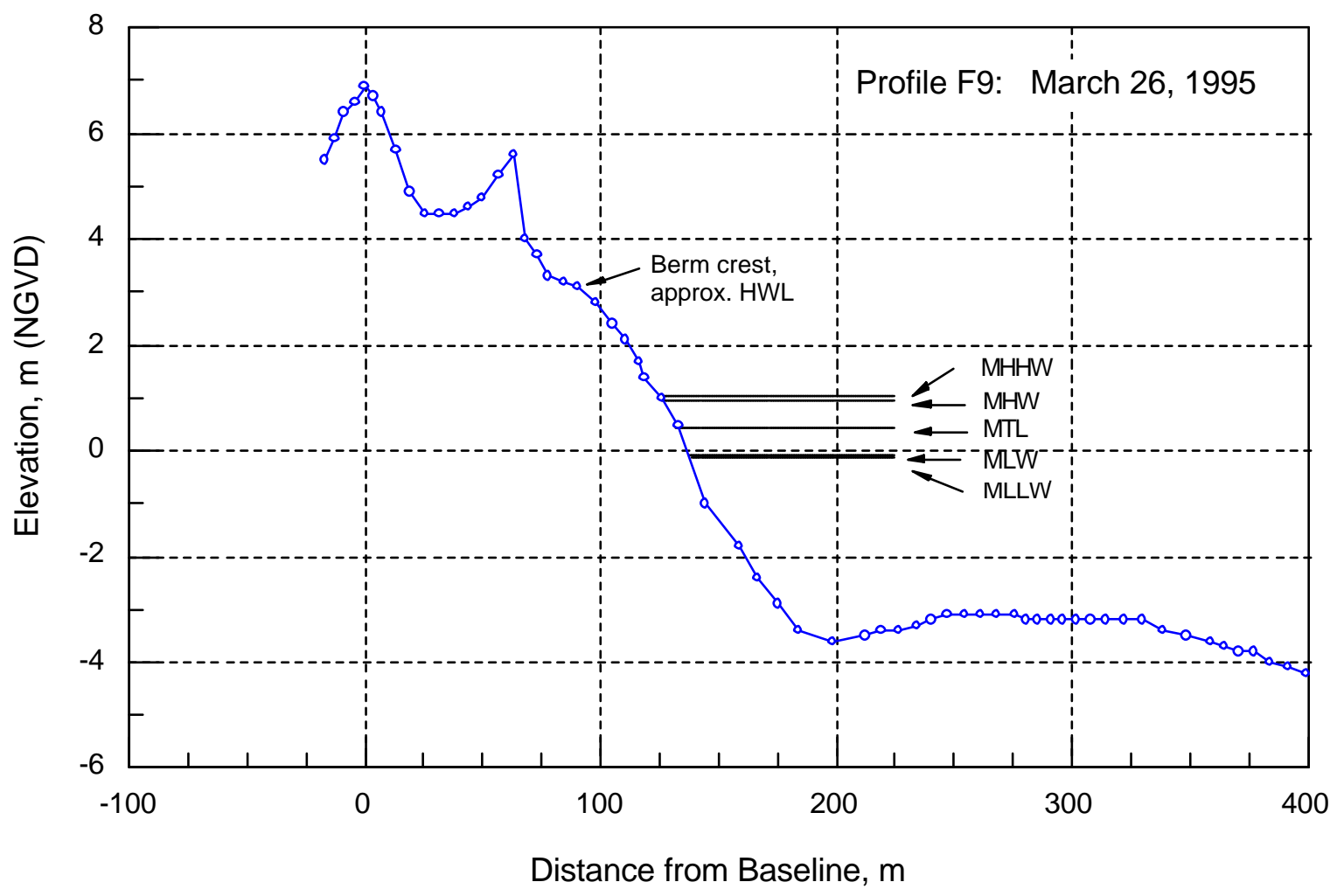

Figure 4b. Fire Island, New York profile survey data, Profile F9, March 26, 1995. 
ADDITIONAL INFORMATION: Questions about this CETN can be addressed to Dr. Nicholas C. Kraus (601-634-2016, Fax 601-634-3080, email: n.kraus@ cerc.wes.army.mil.)) to Ms. Julie Dean Rosati (601-634-3005, Fax 601-634-4314 email: jd.rosati@cerc.wes.army.mil.) or to the manager of the Coastal Inlets Research Program, Mr. E. Clark McNair, (601) 634-2070.

\author{
Definition of Technical Terms and Datums: \\ Berm Crest \\ Foot of Dune \\ Foreshore \\ GPS \\ HWL \\ LSW \\ MHHW \\ MHW \\ MHWL \\ MLLW \\ MLW \\ MSL \\ MTL \\ NAVD 88 \\ NGVD \\ NGVD 29 \\ NTDE \\ SWL \\ Water Line \\ Wetted Bound \\ Accretionary morphologic feature interpreted as the HWL. \\ Delineation between beach and dune. \\ Region of the beach which lies approximately between low tide and high tide, \\ including the limit of wave runup. \\ Global Positioning System. \\ High Water Line; shoreline position interpreted by visually identifying and \\ mapping a morphologic feature (typically the berm crest). \\ Longshore Sand Wave. \\ Mean Higher High Water tidal datum. \\ Mean High Water tidal datum. \\ Mean High Water shoreline: the intersection of MHW and the shore. \\ Mean Lower Low Water tidal datum. \\ Mean Low Water tidal datum. \\ Mean Sea Level tidal datum. \\ Mean Tide Level; average of MHW and MLW. \\ North American Vertical Datum of 1988. \\ National Geodetic Vertical Datum (also NGVD 29). \\ National Geodetic Vertical Datum of 1929. \\ National Tidal Datum Epoch. \\ Still-Water Level. \\ Line of instantaneous beach-water intercept. \\ Delineation between wet and dry portion of beach.
}

\title{
References
}

Anders, F. J. and Byrnes, M. R. 1991. Accuracy of Shoreline Change Rates as Determined from Maps and Aerial Photographs. Shore \& Beach, 59(1): 17-26.

Byrnes, M. R., McBride, R. A., and Hiland, M. W. 1991. Accuracy Standards and Development of a National Shoreline Change Data Base. Proceedings Coastal Sediments '91, ASCE, NY, 1027-1042.

Byrnes, M. R. and Hiland, M. W. 1995. Large-Scale Sediment Transport Patterns on the Continental Shelf and Influence on Shoreline Response: St. Andrew Sound, Georgia to Nassau Sound, Florida, USA. Marine Geology, 126: 19-43.

Grosskopf, W. G., and Kraus, N. C. 1994. Guidelines for Surveying Beach Nourishment Projects. Shore \& Beach, 62(2): 9-16.

Kraus, N.C. 1997. Distinguishing Cross-Shore and Longshore Processes in Shoreline Change Evaluation. Proceedings 10th Annual National Conference on Beach Preservation Technology, Florida Shore and Beach Preservation Association, Tallahassee, Florida. 
Kraus, N. C. and Heilman, D. J. 1997. Field Measurement Distinguishing the Surveyed Mean HighWater Line and the Average Runup Line. In preparation.

Lyles, S. D., Hickman, L. E., Jr., and Debaugh, H. A., Jr. 1988. Sea Level Variations for the United States 1855-1986. National Oceanic and Atmospheric Administration, National Ocean Service, Rockville, Maryland.

Morton, R. A., Leach, M. P., Paine, J. G., and Cardoza, M. A. 1993. Monitoring Beach Changes Using GPS Surveying Techniques. Journal of Coastal Research, 9(3): 702-720.

Rosati, J. D., and Ebersole, B. A. 1997. Littoral Impacts of Ocean City Inlet, Maryland, USA. Proceedings $25^{\text {th }}$ Coastal Engineering. Conference. ASCE, NY, 2779-2792.

Rosati, J. D., and Kraus, N. C. 1997. Even-Odd Function Analysis of Shoreline Position and Volume Change. Coastal Engineering Technical Note CETN-IV-1-, US Army Engineer Waterways Experiment Station, Coastal and Hydraulics Laboratory, Vicksburg, MS.

Shalowitz, A L. 1962. Shore and Sea Boundaries. Volume 1: Boundary Problems Associated with the Submerged Lands Cases and the Submerged Lands Acts. Publication 10-1, US Dept. of Commerce, Coast and Geodetic Survey, 420 pp.

1964. Shore and Sea Boundaries. (Two vols). Volume Two: Interpretation and Use of Coast and Geodetic Survey Data. Publication 10-1, US Dept. of Commerce, Coast and Geodetic Survey, 749 pp.

Stafford, D. B. 1971. An Aerial Photographic Technique for Beach Erosion Surveys in North Carolina. Technical Memorandum 36, U.S. Army Engineer Waterways Experiment Station, Coastal Engineering Research Center, Vicksburg, MS, 115 pp.

Thevenot, M. M., and Kraus, N. C. 1995. Longshore Sand Waves at Southampton Beach, New York, Observations and Numerical Simulation of Their Movement. Marine Geology. 126: 249-269. 